\title{
Nursing and "being with" in a world with COVID-19: an existentialist look
}

\author{
Enfermagem e "estar com" em um mundo com \\ COVID-19: um olhar existencialista \\ Enfermería y "estar con" en un mundo con COVID-19: \\ una mirada existencialista

\section{Carolina Giordani da Silva \\ Maria da Graça Oliveira Crossetti ${ }^{a}$ Maravilla Giménez-Fernández ${ }^{b}$}

\begin{abstract}
How to cite this article: Silva CG, Crossetti MG0, GiménezFernández M. Nursing and "being with" in a world with COVID-19. an existentialist look. Rev Gaúcha Enferm. 2021;42(spe):e20200383 doi: https://doi.org/10.1590/19831447.2021.20200383
\end{abstract}

aniversidade Federal do Rio Grande do Sul (UFRGS), Escola de Enfermagem, Programam de Pós-Graduação em Enfermagem. Porto Alegre, Rio Grande do Sul, Brasil.

- Universidad Católica San Antonio de Murcia (UCAM). Murcia, Murcia, España.

\begin{abstract}
Objective: To reflect on nursing from an existentialist perspective, in which "being-with" has been shown to be the best type of care in a world with Covid-19.

Method: Reflective theoretical study on nursing in the context of a pandemic using an existentialist philosophical theoretical framework.

Results: Nursing is now perceived by society as a profession whose practices are beyond the clinical conditions that affect individuals who live with this pandemic, as taking care of others is not only performing technical actions, but means, fundamentally, taking sensitive ones, like "being-with" in a present and authentic way.

Final considerations: The pandemic has caused changes in the way human beings relate to the world, leading to reflections on values due to the restrictions imposed by it. In this scenario, nurses becomes visible, being the protagonists in the different care spaces, since the focus of its practice is existential care, which is established through relationships in encounters between beings, thus making "being-with" possible.
\end{abstract}

Keywords: Nursing. Existentialism. Coronavirus infections.

\section{RESUMO}

Objetivo: Refletir a enfermagem sob um olhar existencialista, em que o "estar-com" tem se mostrado como o melhor cuidado no mundo com Covid-19.

Método: Estudo teórico reflexivo sobre a enfermagem no contexto de pandemia, sob referencial teórico filosófico existencialista Resultados: A enfermagem passa a ser percebida pela sociedade como profissão cujas práticas estão para além das condições clínicas que acometem os indivíduos que convivem com esta pandemia, pois cuidar do outro não é somente imprimir ações técnicas, mas fundamentalmente sensíveis, como "estar com" de forma presente e autêntica.

Considerações finais: A pandemia provocou mudanças na maneira do ser humano relacionar-se no mundo, ocasionando a reflexão sobre seus valores pelas restrições que impôs. Neste cenário, a enfermagem torna-se visível, sendo protagonista nos diferentes espaços de cuidado, pois o foco da sua prática é o cuidado existencial, que se estabelece através das relações em encontros entre seres, possibilitando, assim, o"estar com".

Palavras-chave: Enfermagem. Existencialismo. Infecções por coronavírus.

\section{RESUMEN}

Objetivo: Reflexionar sobre la enfermería desde una perspectiva existencialista, en que "estar-con" fue demostrado como el mejor modo cuidado en un mundo con Covid-19.

Método: Estudio teórico reflexivo sobre la enfermería en el contexto de una pandemia bajo el marco teórico filosófico existencialista. Resultados: La enfermería fue percibida por la sociedad como una profesión cuyas prácticas van más allá de las condiciones clínicas de los individuos que conviven con la pandemia, pues cuidar no es solo tomar acciones técnicas, sino también, y fundamentalmente, tomar acciones sensibles, como"estar-con" de una manera presente y auténtica.

Consideraciones finales: La pandemia provocó cambios en la forma en que seres humanos se relacionan con el mundo, ocasionando una reflexión sobre sus valores debido a las restricciones que impone. En este escenario, la enfermería se hace visible, siendo protagonista en los diferentes espacios de cuidado, pues el foco de su práctica es el cuidado existencial, que se establece por medio de relaciones en los encuentros entre seres, posibilitando así "estar-con".

Palabras clave: Enfermería. Existencialismo. Infecciones por coronavirus. 


\section{口INTRODUCTION}

The year 2020 started with the announcement that the world might face a pandemic of gargantuan proportions, due to a virus discovered in China at the end of 2019: the so called COVID-19. Crossing the borders of China, the virus quickly made its way into European countries such as Italy, Spain, France, Germany, among others, and on March 11th, it was declared to be a pandemic, with 13,575,158 confirmed cases throughout the world. Currently, there are 1,437,220 confirmed cases in Spain ${ }^{(1)}$ and 5,590,025 in Brazil. In the state Rio Grande do Sul alone there are 235,272 cases $^{(2)}$.

COVID-19 is a disease caused by the coronavirus SARSCoV-2, which presents a clinical framework that varies from asymptomatic infections to severe respiratory problems ${ }^{(3)}$. According to the World Health Organization ${ }^{(3)}$ and the Brazilian Ministry of Health ${ }^{(2)}$, most patients infected by the new coronavirus, nearly $80 \%$, could be asymptomatic. However, nearly $20 \%$ of cases may require hospital attention due to respiratory difficulties, and approximately $5 \%$ of these can require equipment for the treatment of respiratory failure, that is, they may need ventilatory support.

Apparently, the virus showed low lethality, prevalent in those above 60 years of age. The disease is more severe in people with chronic noncommunicable diseases, associated to cardiovascular diseases (hypertension, heart failure, and strokes), chronic respiratory diseases, diabetes, and cancer; these patients are more likely to develop severe COVID-19 conditions $^{(3)}$.

According to the last epidemiological bulletin, issue 36, made available by the Brazilian Ministry of Health,249,096 (56.3\%) cases of Severe Acute Respiratory Syndrome (SARS) caused by COVID-19 affected males, and the most common age group is still from 60 to 69 years old, with 91,157 (20.6\%) people affected. The most prevalent race/color is white $(154,668 ; 34.9 \%)$, followed by brown $(149,762 ; 33.8 \%)$, black $(21,120 ; 4.8 \%)$, yellow $(4,776 ; 1.1 \%)$, and native $(1,542 ; 0.3 \%)^{(4)}$.

The exponential capacity the new coronavirus has of spreading is a challenge for the world's health system, due to the high number of infected people and to the demand for resources needed to confront it. Many countries present expressive numbers of diseased people that require hospitalization and intensive care in hospitals(5).

Furthermore, there is a considerable number of health professionals who are contaminated, and, as such, are excused from work; the nursing team stands out with this regard.

In Brazil, nursing workers are nearly 2.2 million, and act in different regions. It is the category of workers in the frontlines of health care, regardless of the type of attention and of the situation of the disease, pandemic or not ${ }^{(5)}$. According to the nursing observatory, a website created by the Federal Nursing Council (COFEN) to record the number of cases and deaths by COVID-19 that affect those protected by the council, there have been people infected, with 460 deaths in Brazil, with 4,006 cases and 14 deaths in Rio Grande do Sul(6).

Extreme social isolation measures adopted by some of the countries that were affected the most at the start of the pandemic, such as Italy and Spain, and the lack of a specific and effective treatment, led the population of the world to experience feelings of fear, sadness, fright, and despair, considering the number of deaths that increases every day. In addition, symptoms of depression and anxiety emerged due to the uncertainty about the future ${ }^{(7)}$. These feelings express the existential condition of human beings as the unique beings they are, and are believed to set qualitative evidences, since they are inserted in the aesthetic dimension of the human being.

The existential condition refers to man as a single being, which is shown in daily life through forms of expression that can be authentic and personal; or unauthentic and impersonal. From an existential perspective, human beings have the ability to see, mean, and appropriate the things of the world from their own perspective. The starting point of existentialism is the analysis of a concrete and experienced life, and each man is its object of study, being understood as an experience in which he does not stop being for himself(8).

This is the condition that made it possible for men to reinvent themselves in different contexts, due to the COVID-19 pandemic. Personal relations became virtual, while hugs and "being-with" were never so valued, since each man is a "being-in-the-world". Its existence is constituted considering the possibilities of existing, making choices, but especially of relating to others, which makes men unique beings $s^{(8)}$.

Considering a setting in which a disease still does not have an efficient medical treatment for its cure, the role of nursing professionals in the health team stands out, since, regarding COVID-19, the best therapy is care, is "being with", or "being together". Therefore, nursing care must be authentic, not a simple follow up of the patient, and must, especially, encourage the building of affinity, since the nurse and the patient share experiences. In this process, both understand and learn how to establish connections that lead to the unveiling of different worlds, deepening, as a result, a relation of care $^{(8)}$.

Thus, in the current context, in which the world needed to rethink its way to relate, nursing, as a social and humanistic structure, has shown society its way of being, knowing and 
doing, structured in philosophical theoretical references that guide its clinical practice, considering human beings in their existential condition, in which an authentic presence is valued. Therefore, at this point in time, "being-with" is a special feature of actors of care, who are understood here to be nurses, and patients and their relatives.

Thus, it becomes relevant to reflect about nursing in this context from an existentialist perspective, according to which the "being-with" has shown itself as the best care possible in a world with COVID-19.

\section{METHOD}

This is a theoretical-reflexive study about nursing in the context of the pandemic, taking into account the existentialist theoretical philosophical references.

\section{Nursing - the "beings-in-the-world" with the main role in times of Covid-19}

in a world with COVID-19, individuals are living with uncertainties and anxiety, among other ways of existing in this context, revealing that the prospect of a better future is met by them with disbelief ${ }^{(5)}$. In this reality, the need to find an attentive look emerges, one that is capable of expressing embracement in the different health services, showing approximation, being with another in spaces for social interaction.

Nursing, in this setting, is noticed by society no longer as profession structured by mere technical procedures, but stands out due to its empirical and ethical commitment, whose practices are based on scientific fundaments and on the best evidences available ${ }^{(9)}$.

Studies have pointed out that nursing professionals inserted, in this context, as a health care frontline, also show anguish, anxiety, depression, and stress, especially due to the lack of control over the situation, the fear for their health and that of their families, and considering the fast propagation of the virus ${ }^{(10-11)}$. As is the case of patients, workers also need to receive support and emotional support from managers and from the community, since these "beings-of-care" are "beings-in-the-world" who also need care.

According to Heidegger ${ }^{(8)}$, men is "cared for" because he "cares", ontologically, for himself and others, letting them appear or coexist. Therefore, the "care" is an essential part of existence, from the phenomenological-existential understanding of men, or the "being-there". For the philosopher, the "being-there" is always" "being-in-the-world-with", as an opening which unveils the meaning of everything that comes to meet it: therefore, it is always an understanding at its most unique being. Therefore, care is the ontological-existential unit of the "being-there", which precedes itself by "beingthere-in-the-world", such as being together with beings or others who come to meet it in the world. In nursing, this care becomes a reality every time the "beings-there" meet, that is, beings that care, nurses, and beings that are cared for, patients, meet, in a context of relations, the environment of care, coexisting and sharing feelings such as "beings-inthe-world-of-COVID-19", translated as "concern", where both seek ways to cope with this imposed reality.

In this context, caring for the other is not only to provide them with technical actions, but, fundamentally, with actions that are sensitive, such as "being with" in a present and authentic way, at every moment where there is an encounter for the provision of care ${ }^{(8-12)}$, understanding the authentic being as the one who shows himself as he is, recognizing his fears and anguishes, but seeking possibilities of continuing to exist.

In times of COVID-19, in which the main action against the virus is isolation and/or social distancing due to the high-transmissibility of the virus, it is important to understand, from this existentialist perspective, that although the disease is a fact, it is understood, at the moment, as the loss of freedom. This leads to a limitation of the possibilities of relating, since the "being-there" is removed from his world, which makes society as a whole diseased to a certain extent, either because they contracted the coronavirus, or because their freedom was impaired.

In this setting in which it is impossible to exist in the world, nurses, understood as actors of care, are perceived as the professionals with the main role in the field of health, since they seek possibilities of continuing with the patient and their relatives, acting as mediators in the interaction between the beings involved in the process of interdisciplinary care, resorting to tools that can offer a better quality of life ${ }^{(13)}$.

To do so, nurses must be attentive to its possibilities of being and making health, understanding that, if existential suffering is always related to the restriction of the meaning of freedom, the forms of therapeutic care that do not assume their place are restricted to a circle formed by the same horizon of possibilities and to the same logic that produces knowledge. Therefore, one must always consider the individuality of being, understanding this being as a "being-in-the-world-with", which is permeated by feelings and relations that interfere in the state of health ${ }^{(14)}$.

As a result, this pandemic brings in its wake the need for rethinking the presence of the human being in this world, his "being with" another, due to which the growth of virtual relations through messages and personal distancing. 
Therefore, "being-with" shows itself as the existential need of receiving a hug, looking in one's eyes, and being embraced and listened to.

Coronavirus consolidated and extended strategies adopted to amplify the relations of embracement beyond those established by finding direct health care in the different health environments. Practices such as tele-medicine and tele-nursing, as well as the attention offered through telephonic calls in certain specialties, were widened and strengthened through videos, propagandas, and from virtual requests from professionals to the community, condition that, equally, expresses a form of care, since it is being in a common-unity ${ }^{(12)}$.

A common-unity is here understood as the result of many men or human beings struggling for a common purpose, who can be and be more, such as in the case of confronting the coronavirus. It is the individual space of this unique being - the "being-there", together with other "beings-there", also unique, who, through the intersubjective sharing of meanings, become a "being-there-with-another-in-the-world". The phenomenon of nursing is the space in which human beings are comforted and cared, the same where relations take place, where "being-together" makes it so the fear of facing COVID-19 disappears, and possibilities of a continued existence as "being-in-the-world" are glimpsed at ${ }^{(12,14-15)}$.

Therefore, despite the fear and anguish present in the "beings-in-the-world" ${ }^{(8)}$, in one degree or another, as the beings they are, in times of COVID-19, nursing reiterates its commitment and social responsibility as it seeks alternatives to care, learn to "be-with-the-other", and share fears, saying: "We are also afraid, but we are here, together, and as such we will be able to win".

Therefore, the importance of actions of care that were carried out in many health facilities stands out, such as the use of music to better the mood of the environment, motivate the patients for them to give strength to each other in this moment, changing name badges so patients could see the faces of those who were caring for them, playing the guitar and singing for the patients together with other health professionals, in addition to all other necessary interventions for each patient, in their uniqueness.

Motivation, in this setting, is essential, since, existentially, it guides one to overcome, transcend the challenges, and to find new possibilities of continuing to be and exist ${ }^{(8)}$. This form of care, though motivating, is not an action restricted to patient beings. It also extends to nursing professionals, who need to feel supported and motivated to live in the current setting, reinforcing their role as a discipline in the field of health, being protagonists as they"are-with"the other "beings-in-the-world" of care in times of COVID-19.

\section{FINAL CONSIDERATIONS}

The COVID-19 pandemic has changed the lifestyles of humans, and the way in which they relate in the world as a whole, which has led, in general, to reflections on values and world views, due to the restrictions this disease imposed. In this context, nursing becomes visible, and has the main role in the different spaces of care, since the main focus of its practice is the existential care, which is established by relations between beings, thus allowing for the "being-with". This existential condition is expressed through an opening of "beings-of-care" through many diverse and particular possibilities of being in this world in a united and shared manner.

Therefore, it stands out how important it is for nursing, as a science and an art structured in existentialist philosophical theoretical references, to understand the needs of human beings in their uniqueness, thus implementing authentic care in its being-with-the-other-in-the-world with COVID-19.

\section{REFERENCES}

1. Ministerio de Sanidad, Consumo y Bienestar Social (ES) [Internet]. Madri c2020 [citado 2020 out 12]. Situación actual; [about 1 screen]. Available from: https:// www.mscbs.gob.es/profesionales/saludPublica/ccayes/alertasActual/nCov/ situacionActual.htm

2. Ministério da Saúde (BR) [Internet]. Brasília, DF; c2020 [citado 2020 jul 12]. Covid-19 Painel Coronavírus; [about 1 screen]. Available from: https://covid. saude.gov.br/

3. Organización Mundial de la Salud (CH) [Internet]. Geneva; OMS; c2020 [citado 2020 jul 19]. Brote de enfermidade por coronavirus (Covid-19); [about 1 screen]. Available from: https://www.who.int/es/emergencies/diseases/ novel-coronavirus-2019

4. Ministério da Saúde (BR). Secretaria de Vigilância em Saúde. Doença pelo Coronavírus Covid-19. Boletim Epidemiol. 2020 [cited 2020 Jul 12];(36 esp):169. Available from: https://www.gov.br/saude/pt-br/media/pdf/2020/ outubro/23/boletim_epidemiologico_covid_36_final.pdf

5. Miranda FMA, Santana LL, Pizzolato AC, Saquis LMM. Working conditions and the impact on the health of the nursing professionals in the context of covid-19. Cogitare Enferm. 2020;25:e72702. doi: https://doi.org/10.5380/ ce.v25i0.72702

6. Conselho Federal de Enfermagem (BR) [Internet]. Brasilia, DF: Cofen; c2020 [citado 2020 jul 12]. Observatório da Enfermagem; [about 1 screen]. Available from: http://observatoriodaenfermagem.cofen.gov.br

7. Heidergger M. 0 ser e 0 tempo. 3 a ed. Petrópolis: Vozes; 2008.

8. Torres Contrera CC. COVID-19 Pandemics: an opportunity to give Nursing global visibility [Editorial]. Rev Gaúcha Enferm. 2020;41:e20200139. doi: https://doi. org/10.1590/1983-1447.2020.20200139

9. Barbosa DJ et al. Fatores de estresse nos profissionais de enfermagem no combate à pandemia da COVID-19: síntese de evidências. Comunic Ciências Saúde. 2020 [cited 2020 Jul 19];31(Suppl 1):31-47. Available from: http://www.escs.edu. br/revistaccs/index.php/comunicacaoemcienciasdasaude/article/view/651 
10. Dal'Bosco EB. Floriano LSM, Skupien SV, Arcaro G, Martins AR, Anselmo ACC. Mental health of nursing in coping with COVID-19 at a regional university hospital. Rev Bras Enferm. 2020;73(Suppl 2):e20200434. doi: https://doi. org/10.1590/0034-7167-2020-0434

11. Paterson JE, Zderad LT. Enfermería humanística. Ciudad de México: Editora Limusa; 1979

12. Silva VA, Marcon SS, Sales CA. Percepções de familiares de pessoas portadoras de câncer sobre encontros musicais durante o tratamento antineoplásico. Rev Bras Enferm. 2014;67(3):408-14. doi: https://doi. org/10.5935/0034-7167.20140054

\section{- Acknowledgments:}

This study was financed in part by the Coordenação de Aperfeiçoamento de Pessoal de Nível Superior - Brasil (CAPES) - Finance Code 001

\section{- Authorship contributions:}

Conceptualization - Carolina Giordani da Silva.

Methodology - Carolina Giordani da Silva.

Supervision - Maria da Graça Oliveira Crossetti,

Maravilla Giménez-Fernández.

Writing - original draft - Carolina Giordani da

Silva, Maria da Graça Oliveira Crossetti, Maravilla

Giménez-Fernández.

Writing - review: Maria da Graça Oliveira Crossetti,

Maravilla Giménez-Fernández; Edition: Carolina

Giordani da Silva.

\section{- Corresponding author:}

Carolina Giordani da Silva

Email: carol.giordani@gmail.com
13. Santos DG, Sá RN. A existência como "cuidado": elaborações fenomenológicas sobre a psicoterapia na contemporaneidade. Rev Abordagem Gestalt. 2013 [cited 2020 Jul 19];19(1):53-9. Available from: http://pepsic.bvsalud.org/pdf/ rag/v19n1/v19n1a07.pdf

14. Silva AV, Santos I, Kestenberg CCS, Caldas CP, Berardinelli LMM, Silva LPS. On-call listening: an application of Humanistic Theory in the clinical nursing process. Rev Enferm UERJ. 2018;26:e33586. doi: https://doi.org/10.12957/reuerj.2018.33586

15. Hoeck B, Delmar C. Theoretical development in the contexto of nursing: the hidden epistemology of nursing theory. Nurs Philos. 2018;19:e12196. doi: https://doi.org/10.1111/nup.12196

\section{Associate editor:}

Dagmar Elaine Kaiser

\section{Editor-in-chief:}

Received: 09.24.2020

Maria da Graça Oliveira Crossetti 